\title{
PENGARUH KEPERCAYAAN DAN RISIKO TERPERSEPSI TERHADAP KEPUTUSAN PEMBELIAN DARING DENGAN HARGA TERPERSEPSI SEBAGAI VARIABEL PEMODERASI (STUDI KASUS PADA SHOPEE INDONESIA)
}

\author{
Tisia Priskila \\ ${ }^{1}$ Universitas Bunda Mulia \\ tpriskila@bundamulia.ac.id
}

\begin{abstract}
This study aims to determine the effect of trust and risk perception on online purchasing decisions and the influence of price perception as a moderator variable on trust, risk perception, and online purchasing decisions. The analysis method used is PLS-SEM (Partial Least Square-Structural Equation Modeling) with a sample of 100 respondents. The results show that trust has a positive effect on online purchasing decisions and perceived risk has a negative effect on online purchasing decisions. Perceived price as a moderating variable weakens the influence of trust on online purchasing decisions but it does not have an influence on the relationship between risk perception and online buying decisions.
\end{abstract}

Keywords: trust, perceived risk, perceived price, purchase decision

\begin{abstract}
ABSTRAK
Penelitian ini bertujuan mengetahui pengaruh kepercayaan dan risiko terpersepsi terhadap keputusan pembelian daring serta pengaruh harga terpersepsi sebagai variabel pemoderasi terhadap kepercayaan, risiko terpersepsi, dan keputusan pembelian daring. Teknik analisis yang digunakan dalam penelitian ini adalah PLS-SEM (Partial Least Square-Structural Equation Modeling) dengan sampel sebanyak 100 responden. Hasil penelitian menunjukkan bahwa kepercayaan berpengaruh positif terhadap keputusan pembelian daring dan risiko terpersepsi berpengaruh negatif terhadap keputusan pembelian daring. Harga terpersepsi sebagai variabel pemoderasi memperlemah pengaruh kepercayaan terhadap keputusan pembelian daring tetapi tidak memiliki pengaruh terhadap keterkaitan antara risiko terpersepsi dengan keputusan pembeluan daring.

Kata kunci: kepercayaan, risiko terpersepsi, harga terpersepsi, keputusan pembelian
\end{abstract}

\section{PENDAHULUAN}

Indonesia merupakan negara dengan pertumbuhan online marketplace (ecommerce) yang cukup pesat beberapa tahun terakhir ini. (Puspitasari, 2018). Pertumbuhan ini menciptakan fenomena shifting atau yang dikenal dengan pergeseran perilaku belanja konsumen. Perilaku belanja konsumen melalui toko fisik sekarang telah bergeser menjadi perilaku belanja konsumen melalui platform $e$ commerce. Perilaku belanja daring pun sekarang bergeser dari awalnya mengakses $e$ commerce di laptop atau komputer menjadi mobile atau gadget (Putera, 2018)

Keputusan pembelian merupakan perilaku yang timbul karena adanya rangsangan atau hubungan dari pihak lain (Kotler, 2011).
Menurut Mohmed, Azizan, dan Jali (2013), kepercayaan merupakan faktor terkuat yang memengaruhi keputusan pembelian daring. Kepercayaan merupakan faktor penting yang dapat memengaruhi konsumen untuk membeli produk secara daring.

Kepercayaan dapat diartikan sebagai kesediaan konsumen dalam mempercayai situs belanja daring sehingga terciptanya transaksi jual beli. Hanya pelanggan yang memiliki kepercayaan yang berani melakukan transaksi melalui media daring. Beberapa kasus yang terjadi akibat kurangnya integritas dan tanggung jawab dari penjual di platform ecommerce membuat faktor kepercayaan menjadi hal yang sangat diperhatikan oleh konsumen daring. 
Versi Online: http://journal.ubm.ac.id/

Hasil Penelitian

Menurut penelitian Ashoer dan Sahid (2016), keputusan pembelian daring juga dipengaruhi oleh risiko terpersepsi. Risiko terpersepsi adalah ketidakpastian mengenai konsekuensi negatif yang mungkin timbul dari penggunaan produk atau jasa (Demirdogen, 2010).

Risiko terpersepsi merupakan salah satu faktor yang membuat konsumen enggan berbelanja daring. Tidak dapat dipungkiri, risiko pasti minimal dirasakan oleh konsumen karena tidak melihat wujud asli dari produk yang mereka butuhkan. Apalagi akhir-akhir ini banyak terjadinya kasus penipuan di toko daring termasuk salah satunya Shopee Indonesia. Banyak review dari konsumen tentang kasus penipuan penjual token listrik atau produk yang dijual di platform Shopee Indonesia. Ini tentunya meningkatkan risiko terpersepsi konsumen terhadap keputusan pembelian daring.

Semakin besar risiko terpersepsi yang dirasakan konsumen maka keputusan pembelian daring akan semakin rendah. Risiko terpersepsi terbagi ke dalam risiko keuangan, risiko produk, risiko informasi, dan risiko pengiriman (Martiyanti, 2015). Risiko keuangan berkaitan dengan risiko yang mungkin terjadi saat melakukan pembayaran. Risiko produk berkaitan dengan kualitas produk, kepalsuan produk, produk tidak sesuai dengan spesifikasi. Risiko informasi berkaitan dengan ketidaksesuaian informasi mengenai penjual atau produk. Risiko pengiriman berkaitan dengan perhatian konsumen mengenai proses pengiriman barang.

Harga terpersepsi diyakini dapat memengaruhi keterkaitan antara kepercayaan, risiko terpersepsi, dan keputusan pembelian daring konsumen. Menurut Setiawan dan Achyar (2012), harga terpersepsi berpengaruh negatif terhadap nilai yang didapat pelanggan dan keputusan pembelian daring.

Penelitian ini bertujuan untuk mengetahui pengaruh kepercayaan dan risiko terpersepsi terhadap keputusan pembelian daring serta pengaruh harga terpersepsi sebagai variabel pemoderasi terhadap
Business Management Journal

Vol.14 (No. 2 ) : 75 - 153. Th. 2018

ISSN: 1907-0896

E-ISSN: 2598-6775

kepercayaan, risiko terpersepsi, dan keputusan pembelian daring.

\section{TINJAUAN PUSTAKA}

\section{Keputusan Pembelian}

Keputusan pembelian adalah proses keputusan pembelian terdiri dari lima tahap yang dilakukan oleh seorang konsumen sebelum sampai pada keputusan pembelian dan selanjutnya pasca pembelian (Kotler dan Keller, 2012).

Menurut Kotler dan Armstrong (2012), konsumen akan melewati lima tahap proses keputusan pembelian yaitu: pengenalan kebutuhan, pencarian informasi, evaluasi alternatif, keputusan pembelian, dan perilaku pasca pembelian.

\section{Kepercayaan}

Kepercayaan adalah kesediaan konsumen untuk menerima kerentanan dan melakukan transaksi daring berdasarkan harapannya yang positif mengenai perilaku berbelanja daring pada masa mendatang (Suryani, 2013). Adanya faktor kepercayaan yang dibangun oleh pelaku bisnis dapat menarik minat konsumen untuk berbelanja daring melalui website yang dibangun (Harris dan Goode, 2010).

Dimensi kepercayaan meliputi keamanan (sejauh mana pelanggan percaya bahwa transaksi daring aman bagi mereka untuk memberikan informasi sensitif), privasi, dan keandalan (reputasi positif dari e-commerce).

\section{Risiko Terpersepsi}

Risiko terpersepsi adalah ketidakpastian mengenai konsekuensi negatif yang mungkin timbul dari penggunaan produk atau jasa (Demirdogen, 2010).

Adanya faktor-faktor yang memengaruhi risiko terpersepsi (Martiyanti, 2015) yaitu risiko keuangan, risiko produk, risiko informasi, dan risiko pengiriman. Risiko keuangan berkaitan dengan risiko yang mungkin terjadi saat melakukan pembayaran. Risiko produk berkaitan dengan kualitas produk, kepalsuan produk, produk tidak sesuai 
dengan spesifikasi. Risiko informasi berkaitan dengan ketidaksesuaian informasi mengenai penjual atau produk. Risiko pengiriman berkaitan dengan perhatian konsumen mengenai proses pengiriman barang.

\section{Harga Terpersepsi}

Harga terpersepsi adalah bagaimana informasi harga dipahami seluruhnya oleh konsumen dan memberikan makna yang dalam bagi mereka. Pada saat konsumen melakukan evaluasi dan penelitian terhadap harga dari suatu produk sangat dipengaruhi oleh perilaku dari konsumen itu sendiri.

Menurut Kotler dan Armstrong (2012), ada 4 dimensi harga yaitu keterjangkauan harga, kesesuaian harga dengan kualitas, daya saing harga, dan kesesuaian harga dengan manfaat.

Tabel 1. Penelitian Terdahulu

\begin{tabular}{|c|c|c|c|c|c|}
\hline No. & Peneliti & Tahun & Judul Penelitian & Metode & Hasil \\
\hline 1 & $\begin{array}{l}\text { Setiawan } \\
\text { dan Achyar }\end{array}$ & 2012 & $\begin{array}{l}\text { Effects of Perceived } \\
\text { Trust and Perceived } \\
\text { Price on Customers' } \\
\text { Intention to Buy in } \\
\text { Daring Store in } \\
\text { Indonesia. }\end{array}$ & $\begin{array}{l}\text { Metode } \\
\text { Kuantitatif }\end{array}$ & $\begin{array}{l}\text { Kepercayaan berpengaruh positif } \\
\text { terhadap minat pembelian daring } \\
\text { konsumen sedangkan harga } \\
\text { terpersepsi berpengaruh negatif } \\
\text { terhadap nilai yang didapat } \\
\text { pelanggan dan keinginan untuk } \\
\text { membeli daring. }\end{array}$ \\
\hline 2 & $\begin{array}{l}\text { Mohmed, } \\
\text { Azizan, dan } \\
\text { Jali }\end{array}$ & 2013 & $\begin{array}{l}\text { The Impact of Trust } \\
\text { and Past Experience } \\
\text { on Intention to } \\
\text { Purchase in E- } \\
\text { Commerce }\end{array}$ & $\begin{array}{l}\text { Metode } \\
\text { Kuantitatif }\end{array}$ & $\begin{array}{l}\text { Kepercayaan dan pengalaman } \\
\text { terdahulu berpengaruh terhadap } \\
\text { minat pembelian daring konsumen. } \\
\text { Kepercayaan adalah faktor terkuat } \\
\text { yang memengaruhi minat pembelian } \\
\text { daring. }\end{array}$ \\
\hline 3 & $\begin{array}{l}\text { Broillet, } \\
\text { Dubosson, } \\
\text { and Varone }\end{array}$ & 2014 & \begin{tabular}{lr}
\multicolumn{2}{l}{ Risk Awareness from } \\
the Consumer's & Side \\
in Luxury E- & Commerce: \\
Empirical Study &
\end{tabular} & $\begin{array}{l}\text { Metode } \\
\text { Kuantitatif }\end{array}$ & $\begin{array}{l}\text { Walaupun merek mahal menawarkan } \\
\text { jaminan untuk risiko keuangan, } \\
\text { harga, pengiriman, produk, dan } \\
\text { setelah penjualan, tetap tidak akan } \\
\text { mengubah risiko terpersepsi } \\
\text { konsumen untuk melakukan } \\
\text { pembelian daring. }\end{array}$ \\
\hline
\end{tabular}

\begin{tabular}{|c|c|c|c|c|}
\hline 4 & $\begin{array}{l}\text { Ashoer dan } 2016 \\
\text { Said }\end{array}$ & $\begin{array}{l}\text { The Impact of } \\
\text { Perceived Risk on } \\
\text { Consumer Purchase } \\
\text { Intention in } \\
\text { Indonesia; A Social } \\
\text { Commerce Study }\end{array}$ & $\begin{array}{l}\text { Metode } \\
\text { Kuantitatif }\end{array}$ & $\begin{array}{l}\text { Risiko terpersepsi (financial risk, } \\
\text { social risk, product risk, delivery } \\
\text { risk, security and privacy risk, after } \\
\text { sale risk berpengaruh negatif } \\
\text { terhadap minat pembelian daring } \\
\text { konsumen. }\end{array}$ \\
\hline 5 & $\begin{array}{l}\text { Kidane dan } 2016 \\
\text { Sharma }\end{array}$ & $\begin{array}{lr}\text { Factors Affecting } \\
\text { Consumer's } \\
\text { Purchasing } & \text { Decision } \\
\text { Through } & \text { E- } \\
\text { Commerce } & \end{array}$ & $\begin{array}{l}\text { Metode } \\
\text { Kualitatif }\end{array}$ & $\begin{array}{l}\text { Kepercayaaan, } \\
\text { pengembalian, COD, after sale } \\
\text { service, jaminan pengembalian, } \\
\text { reputasi menjadi faktor yang dapat } \\
\text { memengaruhi keputusan pembelian } \\
\text { daring konsumen. }\end{array}$ \\
\hline 6 & $\begin{array}{ll}\text { Sharma dan } 2017 \\
\text { Kurien }\end{array}$ & $\begin{array}{l}\text { Perceived Risk in E- } \\
\text { Commerce: } \\
\text { Demographic } \\
\text { Perspective }\end{array}$ & $\begin{array}{l}\text { Metode } \\
\text { Kuantitatif }\end{array}$ & $\begin{array}{l}\text { Risiko terpersepsi (product risk, } \\
\text { financial risk, security and privacy } \\
\text { risk) berpengaruh signifikan terhadap } \\
\text { keputusan pembelian daring } \\
\text { konsumen. }\end{array}$ \\
\hline
\end{tabular}


Versi Online: http://journal.ubm.ac.id/ Hasil Penelitian

\section{Desain Penelitian}

Keterkaitan Kepercayaan, Risiko Terpersepsi, Harga Terpersepsi, dan Keputusan Pembelian Daring

Berdasarkan penelitian Kidane dan Sharma (2016), Mohmed et al. (2013), dan Setiawan dan Achyar (2012) menyatakan bahwa kepercayaan merupakan faktor yang dapat memengaruhi keputusan pembelian daring konsumen. Kepercayaan konsumen terhadap suatu e-commerce yang dimaksud adalah keamanan, privasi, dan keandalan. Semakin tinggi tingkat kepercayaan yang dirasakan konsumen maka tingkat keputusan pembelian daring akan semakin meningkat.

Berdasarkan penelitian Ashoer dan Said (2016) dan Sharma dan Kurien (2017) menyatakan bahwa risiko terpersepsi merupakan faktor yang dapat memengaruhi keputusan pembelian daring konsumen. Risiko terpersepsi terhadap suatu e-commerce yang dimaksud adalah risiko keuangan, risiko produk, risiko informasi, dan risiko pengiriman. Semakin tinggi risiko terpersepsi yang dirasakan konsumen maka tingkat keputusan pembelian daring akan seakin rendah.

Harga terpersepsi diyakini dapat memengaruhi keterkaitan antara kepercayaan, risiko terpersepsi, dan keputusan pembelian daring konsumen. Berdasarkan penelitian Setiawan dan Achyar (2012), harga terpersepsi berpengaruh terhadap nilai yang didapat pelanggan dan keputusan pembelian daring. Harga terpersepsi yang dimaksud adalah keterjangkauan harga, kesesuaian harga dengan kualitas, daya saing harga, dan kesesuaian harga dengan manfaat.

Dengan demikian, desain penelitian ini adalah sebagai berikut:

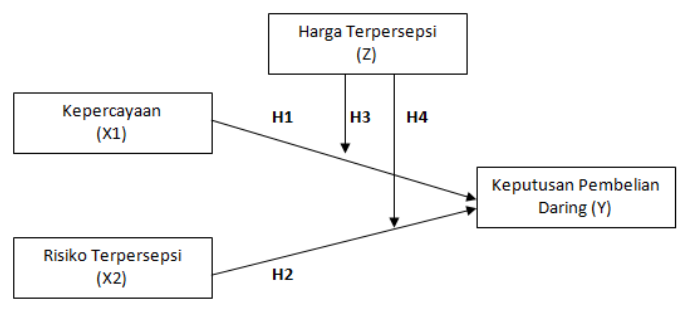

\section{Gambar 1. Model Penelitian}

Sumber: Peneliti

\section{Hipotesis Penelitian}

H1: Keputusan pembelian daring dipengaruhi oleh kepercayaan.

H2: Keputusan pembelian daring dipengaruhi oleh risiko terpersepsi.

H3: Pengaruh kepercayaan terhadap keputusan pembelian daring diperkuat/diperlemah oleh harga terpersepsi.

H4: Pengaruh risiko terpersepsi terhadap keputusan pembelian daring diperkuat/diperlemah oleh harga terpersepsi.

\section{METODE PENELITIAN}

\section{Jenis dan Sumber Data Penelitian}

Jenis penelitian ini adalah penelitian deskriptif dengan pendekatan kuantitatif. Sumber data penelitian ini yaitu data primer (kuesioner terstruktur) dan data sekunder (studi kepustakaan, jurnal, literatur, serta penelusuran Internet).

\section{Populasi dan Sampel}

Populasi dalam penelitian ini adalah generasi langgas yang pernah berbelanja di $e$ commerce Shopee dalam kurun waktu satu tahun. Sampel dalam penelitian ini adalah 100 orang responden. Cara penentuan jumlah sampel adalah dengan mengalikan aturan minimal dalam metode PLS sebanyak 5 (lima) dengan jumlah indikator yang digunakan (20 indikator). Teknik pengambilan sampel menggunakan teknik pengambilan sampel acak sederhana (simple random sampling).

\section{Metode Analisis Data}

Metode analisis data menggunakan PLSSEM dengan bantuan program SmartPLS 3.0. Penilaian model pengukuran (outer model) bertujuan menguji validitas konstruk dan reliabilitas instrumen.

Untuk uji validitas konstruk digunakan metode validitas konvergen (nilai AVE $\geq$ 0.50) dan validitas diskriminan (nilai factor 
loading $\geq$ nilai cross loading). Untuk uji reliabilitas digunakan metode reliabilitas indikator (nilai factor loading $\geq 0.40$ ) dan metode reliabilitas konsistensi internal (Composite Reliability $\geq 0.70$ dan Cronbach's Alpha $\geq 0.60$ ).

Penilaian model struktural (inner model) dilakukan dengan menggunakan metode bootstrap (metode non-parametric) dikarenakan PLS tidak menggunakan asumsi data terdistribusi normal (Hair et al., 2014). Skor koefisien jalur atau inner model yang ditunjukkan oleh nilai t-statistic harus lebih besar dari nilai t-tabel pengujian dua arah $(>1,98)$ dengan $\alpha=5 \%$.

Untuk melihat besarnya keterubahan peubah keputusan pembelian dapat dilihat melalui koefisien determinasi.

\section{HASIL DAN PEMBAHASAN}

\section{Profil Responden}

Adapun karakteristik 100 orang responden dalam penelitian ini telah dirangkum dalam Tabel 2.

Tabel 2. Profil Responden

\begin{tabular}{|c|c|c|c|}
\hline No. & Profil & Kategori & Persentase (\%) \\
\hline \multirow{2}{*}{1} & \multirow{2}{*}{ Gender } & Laki-laki & 25 \\
\hline & & Perempuan & 75 \\
\hline \multirow{2}{*}{2} & \multirow{2}{*}{ Usia } & $16-25$ tahun & 86 \\
\hline & & $26-35$ tahun & 14 \\
\hline \multirow{3}{*}{3} & \multirow{3}{*}{ Pekerjaan } & Pegawai Swasta & 19 \\
\hline & & Pelajar / Mahasiswa & 76 \\
\hline & & Wirausaha & 5 \\
\hline \multirow{4}{*}{4} & \multirow{4}{*}{$\begin{array}{l}\text { Penghasilan / Uang Saku } \\
\text { per bulan }\end{array}$} & Di bawah Rp. 1.000 .000 & 30 \\
\hline & & Rp. 1.000.000 - Rp. 5.000.000 & 56 \\
\hline & & Rp. $5.000 .000-$ Rp. 10.000 .000 & 13 \\
\hline & & Di atas Rp. 10.000 .000 & 1 \\
\hline \multirow{2}{*}{5} & \multirow{2}{*}{$\begin{array}{l}\text { Mengetahui E-commerce } \\
\text { Shopee }\end{array}$} & Ya & 100 \\
\hline & & Tidak & 0 \\
\hline \multirow{2}{*}{6} & \multirow{2}{*}{$\begin{array}{l}\text { Pernah berbelanja di } \\
\text { Shopee }\end{array}$} & $\mathbf{Y a}$ & 100 \\
\hline & & Tidak & 0 \\
\hline \multirow{3}{*}{7} & \multirow{3}{*}{$\begin{array}{l}\text { Tingkat keseringan } \\
\text { berbelanja di Shopee }\end{array}$} & Jarang (1-3 kali) & 54 \\
\hline & & Kadang-kadang (3-6 kali) & 24 \\
\hline & & Sering ( di atas 6 kali) & 22 \\
\hline
\end{tabular}

Sumber: Hasil Pengolahan Data Primer

\section{Model Pengukuran (Outer Model)}

Uji validitas outer model dilakukan dengan menggunakan validitas konvergen dan validitas diskriminan.

\section{Validitas Konvergen}

Penilaian validitas konvergen dilakukan dengan melihat nilai AVE (AVE $\geq 0,50$ dikatakan valid).

Tabel 3. Nilai AVE

\begin{tabular}{ll}
\hline \multicolumn{1}{c}{ Variabel } & AVE \\
\hline Kepercayaan & 0.568 \\
\hline Risiko terpersepsi & 0.561 \\
\hline Harga terpersepsi & 0.600 \\
\hline Keputusan Pembelian & 0.588 \\
\hline
\end{tabular}

Sumber: Hasil Pengolahan PLS
Tabel 3 menunjukkan hasil AVE yang didapat nilainya di atas 0.50 sehingga dapat dinyatakan indikator penelitian telah memenuhi kriteria validitas.

\section{Validitas Diskriminan}

Penilaian validitas diskriminan dilakukan dengan melihat nilai factor loading lebih besar dari nilai cross loading. 
Versi Online: http://journal.ubm.ac.id/ Hasil Penelitian

Tabel 4. Nilai Cross Loading

\begin{tabular}{|c|c|c|c|c|}
\hline & $\begin{array}{c}\text { Keperc } \\
\text { ayaaan }\end{array}$ & $\begin{array}{c}\text { Risiko } \\
\text { terperse } \\
\text { psi }\end{array}$ & $\begin{array}{c}\text { Harga } \\
\text { terperse } \\
\text { psi }\end{array}$ & $\begin{array}{c}\text { Keputusan } \\
\text { Pembelian }\end{array}$ \\
\hline K1 & $\mathbf{0 . 7 7 6}$ & -0.231 & 0.480 & 0.568 \\
\hline K2 & $\mathbf{0 . 6 9 0}$ & -0.203 & 0.370 & 0.514 \\
\hline K3 & $\mathbf{0 . 8 5 7}$ & -0.225 & 0.554 & 0.648 \\
\hline K4 & $\mathbf{0 . 6 9 6}$ & -0.151 & 0.430 & 0.501 \\
\hline K5 & $\mathbf{0 . 7 3 8}$ & -0.101 & 0.403 & 0.453 \\
\hline PR1 & -0.015 & $\mathbf{0 . 5 0 6}$ & -0.053 & -0.086 \\
\hline PR3 & -0.203 & $\mathbf{0 . 7 5 9}$ & 0.012 & -0.216 \\
\hline PR4 & -0.202 & $\mathbf{0 . 8 3 3}$ & -0.145 & -0.212 \\
\hline PR5 & -0.234 & $\mathbf{0 . 8 4 7}$ & -0.174 & -0.271 \\
\hline PH1 & 0.341 & 0.003 & $\mathbf{0 . 6 8 1}$ & 0.446 \\
\hline PH2 & 0.263 & 0.064 & $\mathbf{0 . 6 7 8}$ & 0.472 \\
\hline PH3 & 0.555 & -0.200 & $\mathbf{0 . 8 4 0}$ & 0.630 \\
\hline PH4 & 0.619 & -0.192 & $\mathbf{0 . 8 7 7}$ & 0.705 \\
\hline KP1 & 0.571 & -0.234 & 0.435 & $\mathbf{0 . 7 2 5}$ \\
\hline KP2 & 0.397 & -0.182 & 0.446 & $\mathbf{0 . 6 2 1}$ \\
\hline KP4 & 0.644 & -0.262 & 0.730 & $\mathbf{0 . 8 7 2}$ \\
\hline KP5 & 0.521 & -0.148 & 0.614 & $\mathbf{0 . 7 6 0}$ \\
\hline KP6 & 0.597 & -0.245 & 0.572 & $\mathbf{0 . 8 3 2}$ \\
\hline
\end{tabular}

Sumber: Hasil Pengolahan PLS

\section{Reliabilitas Indikator}

Uji reliabilitas indikator dalam PLS dinilai berdasarkan nilai loading factor indikator yang mengukur konstruk tersebut. Dikatakan reliabel apabila nilai loading factor $\geq 0.40$ (Hair et al., 2011).

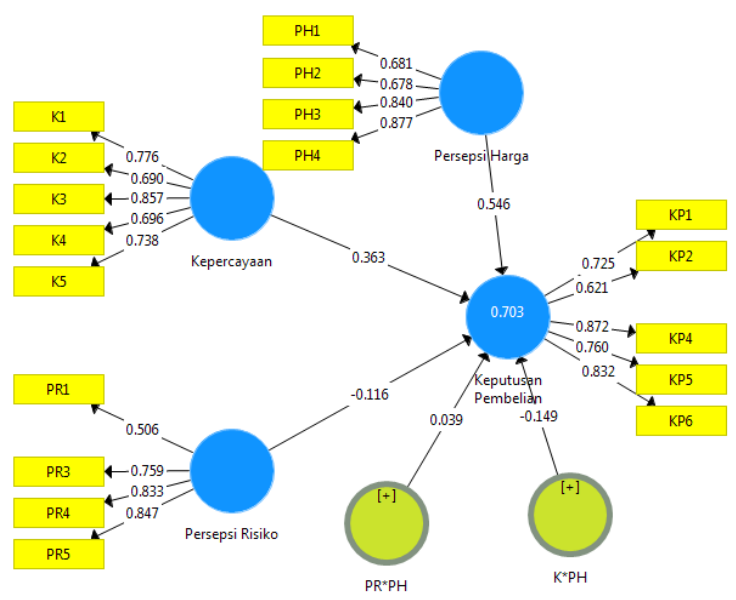

Gambar 2. Loading Factor

Sumber: Hasil Pengolahan PLS

Gambar 2 menunjukkan bahwa seluruh indikator sudah memiliki nilai muatan faktor lebih besar dari 0.4 (indikator telah memenuhi kriteria reliabilitas).
Business Management Journal

\section{Reliabilitas Konsistensi Internal}

Pengujian reliabilitas konsistensi internal dapat dilakukan dengan metode composite reliability dan koefisien Alpha Cronbach. Dikatakan reliabel jika nilai composite reliability $\geq 0.70$ dan nilai koefisien Alpha Cronbach $\geq 0.60$ (Hair et al., 2011)

Tabel 5. Nilai Reliabilitas Konstruk

\begin{tabular}{lcc}
\hline \multicolumn{1}{c}{ Variabel } & $\begin{array}{c}\text { Composite } \\
\text { Reliability }\end{array}$ & $\begin{array}{c}\text { Cronbach's } \\
\text { Alpha }\end{array}$ \\
\hline Kepercayaan & 0.568 & 0.808 \\
\hline $\begin{array}{l}\text { Risiko } \\
\text { terpersepsi }\end{array}$ & 0.561 & 0.740 \\
\hline Harga terpersepsi & 0.600 & 0.777 \\
\hline $\begin{array}{l}\text { Keputusan } \\
\text { Pembelian }\end{array}$ & 0.588 & 0.822 \\
\hline
\end{tabular}

Sumber: Hasil Pengolahan PLS

Tabel 5 menunjukkan bahwa nilai composite reliability untuk semua konstruk berada di atas 0.70 dan nilai koefisien Alpha Cronbach untuk semua konstruk berada di atas 0.60 , sehingga telah memenuhi kriteria reliabilitas.

\section{Model Struktural (Inner Model) \\ Koefisien Determinasi}

Koefisien determinasi $\left(\mathrm{R}^{2}\right)$ digunakan untuk melihat seberapa besar keterubahan variabel independen akibat variabel dependen.

Tabel 6. Koefisien Determinasi

\begin{tabular}{ccc}
\hline Variabel & $\boldsymbol{R}$ Square & $\begin{array}{c}\boldsymbol{R} \text { Square } \\
\text { Adjusted }\end{array}$ \\
\hline Keputusan Pembelian & 0.703 & 0.687 \\
\hline
\end{tabular}

Sumber: Hasil Pengolahan PLS

Tabel 6 menunjukkan bahwa pengaruh kepercayaan dan risiko terpersepsi secara bersama-sama terhadap keterubahan keputusan pembelian daring adalah sebesar $68.7 \%$. Sisanya, sebanyak $31.3 \%$ dijelaskan oleh variabel lain di luar penelitian.

\section{Uji Hipotesis}

Pengujian hipotesis dilakukan dengan melihat nilai koefisien jalur yang menunjukkan tingkat signifikansi. Skor koefisien jalur atau inner model yang 
ditunjukkan oleh nilai t-statistic harus lebih besar dari nilai t-tabel pengujian dua arah $(>1.98)$ dengan $\alpha=5 \%$. Hasil bootstrap dapat dilihat pada Gambar 3 dan terangkum dalam Tabel 5.

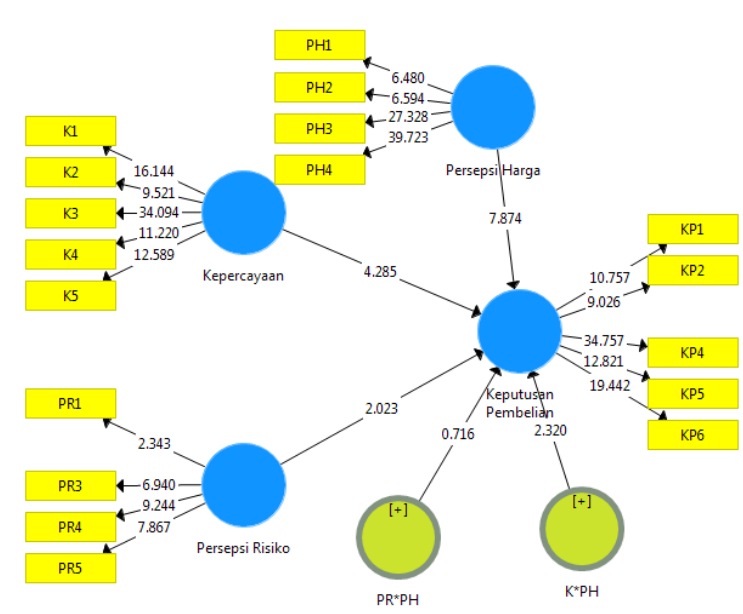

Gambar 3. Hasil Bootstraping

Sumber: Hasil Pengolahan PLS

Tabel 7. Path Coefficient

\begin{tabular}{|c|c|c|c|c|c|}
\hline & Hipotesis & $\begin{array}{l}\text { Koefisien } \\
\text { Jalur }\end{array}$ & $\begin{array}{c}\mathrm{t}- \\
\text { statistics }\end{array}$ & Sig. & Hasil \\
\hline H1 & $\begin{array}{l}\text { Keputusan pembelian daring } \\
\text { dipengaruhi oleh kepercayaan. }\end{array}$ & 0.363 & 4.285 & 0.000 & Diterima \\
\hline $\mathrm{H} 2$ & $\begin{array}{l}\text { Keputusan pembelian daring } \\
\text { dipengaruhi oleh risiko } \\
\text { terpersepsi. }\end{array}$ & -0.116 & 2.023 & 0.043 & Diterima \\
\hline H3 & $\begin{array}{l}\text { Pengaruh kepercayaan terhadap } \\
\text { keputusan pembelian daring } \\
\text { diperkuat/diperlemah oleh harga } \\
\text { terpersepsi. }\end{array}$ & -0.149 & 2.320 & 0.021 & Diterima \\
\hline $\mathrm{H} 4$ & $\begin{array}{l}\text { Pengaruh risiko terpersepsi } \\
\text { terhadap keputusan pembelian } \\
\text { daring diperkuat/diperlemah oleh } \\
\text { harga terpersepsi. }\end{array}$ & 0.039 & 0.716 & 0.474 & Ditolak \\
\hline
\end{tabular}

Tabel 7 menunjukkan bahwa

Hipotesis pertama (H1) memiliki nilai t-hitung sebesar $4.285(>1.98)$ dan nilai signifikansi sebesar 0,000 $(<0.05)$. Dengan demikian, H1 diterima.

Hipotesis kedua (H2) memiliki nilai thitung sebesar $2.023(>1.98)$ dan nilai signifikansi sebesar $0,043 \quad(<0.05)$. Dengan demikian, $\mathrm{H} 2$ diterima.
Hipotesis ketiga (H3) memiliki nilai thitung sebesar $2.320(>1.98)$ dan nilai signifikansi sebesar $0,021 \quad(<0.05)$. Dengan demikian, H3 diterima.

Hipotesis keempat (H4) memiliki nilai t-hitung sebesar $0.716(<1.98)$ dan nilai signifikansi sebesar $0.021 \quad(>0.05)$. Dengan demikian, H4 ditolak.

\section{Pembahasan}

Pengaruh Kepercayaan Terhadap Keputusan Pembelian Daring. 
Hasil penelitian menunjukkan bahwa keputusan pembelian daring dipengaruhi oleh kepercayaan secara positif (sig $0.000<0.05$ dengan niali koefisien jalur 0.363). Artinya, semakin tinggi tingkat kepercayaan yang dirasakan oleh konsumen terhadap $e$ commerce Shopee Indonesia maka tingkat keputusan pembelian daring akan semakin meningkat. Sebaliknya, semakin rendah tingkat kepercayaan yang dirasakan oleh konsumen terhadap e-commerce Shopee Indonesia maka tingkat keputusan pembelian daring akan semakin menurun.

Hasil penelitian ini sejalan dengan penelitian Kidane dan Sharma (2016) yang mengungkapkan kepercayaan merupakan salah satu faktor yang dapat memengaruhi keputusan pembelian daring konsumen. Hasil penelitian ini juga sejalan dengan penelitian Mohmed, Azizan, dan Jali (2013) serta Setiawan dan Achyar (2012) yang mengungkapkan adanya pengaruh yang signifikan antara kepercayaan terhadap keputusan pembelian daring konsumen.

Hasil analisis statistik deskriptif variabel kepercayaan menunjukkan ratarata responden berpersepsi e-commerce Shopee terpercaya baik dari segi penyediaan barang berkualitas, pemberian kategori Star Seller, etikat baik dari penjual Shopee untuk memberikan kepuasan bagi konsumen, reputasi yang baik, serta penjual yang bertanggung jawab. Pemberian kategori Star Seller mendapatkan nilai rerata tertinggi dari responden dimana strategi tersebut akan lebih meningkatkan rasa kepercayaan konsumen untuk berbelanja di Shopee.

Pengaruh Risiko terpersepsi Terhadap Keputusan Pembelian Daring.
Hasil penelitian menunjukkan bahwa keputusan pembelian daring dipengaruhi oleh risiko terpersepsi secara negatif (sig $0.043<0.05$, dengan nilai koefisien jalur -0.116). Artinya, semakin tinggi risiko terpersepsi yang dirasakan oleh konsumen terhadap $e$ commerce Shopee Indonesia, maka tingkat keputusan pembelian daring konsumen akan semakin rendah. Sebaliknya, semakin rendah risiko terpersepsi yang dirasakan oleh konsumen terhadap e-commerce Shopee Indonesia, maka tingkat keputusan pembelian daring konsumen akan semakin tinggi.

Hasil penelitian ini sejalan dengan penelitian Ashoer dan Said (2016) yang mengungkapkan bahwa risiko terpersepsi berpengaruh negatif terhadap minat pembelian daring konsumen. Dimensi risiko terpersepsi yang memengaruhi diantaranya adalah risiko keuangan, risiko sosial, risiko pengiriman, risiko keamanan dan privasi, dan risiko setelah penjualan. Hasil penelitian ini juga sejalan dengan penelitian Sharma dan Kurien (2017) yang mengungkapkan bahwa konsumen akan menunjukkan ketidakinginan mereka untuk membeli dari e-commerce yang dipersepsi beresiko. Dimensi risiko terpersepsi yang memengaruhi diantaranya adalah risiko produk, risiko keuangan, dan risiko keamanan dan privasi.

Hasil analisis statistik deskriptif variabel risiko terpersepsi menunjukkan bahwa risiko terpersepsi konsumen yang menjadi responden penelitian masih rendah terhadap e-commerce Shopee. Konsumen merasa aman melakukan pembayaran, merasa bahwa pengiriman produk di Shopee cepat, serta produk sesuai dengan spesifikasi yang dicantumkan. Hanya saja, rata-rata 
responden masih tinggi terhadap risiko keamanan pemberian informasi pribadi serta risiko tidak lengkapnya informasi yang diberikan. Hal tersebut dapat menjadi pengaruh negatif terhadap keputusan pembelian daring konsumen.

Pengaruh Harga terpersepsi sebagai Variabel Pemoderasi Terhadap Kepercayaan dan Keputusan Pembelian Daring.

Hasil penelitian menunjukkan bahwa kepercayaan dan keputusan pembelian daring dipengaruhi oleh harga terpersepsi sebagai variabel pemoderasi (sig. $0.021<0.05$ ). Tetapi pengaruh harga terpersepsi sebagai variabel pemoderasi memperlemah kepercayaan dan keputusan pembelian daring (nilai koefisien jalur sebesar 0.149 ).

Harga terpersepsi adalah bagaimana informasi harga dipahami seluruhnya oleh konsumen dan memberikan makna yang dalam bagi mereka (Soelistiyo, 2016). Ketika konsumen melihat perbandingan harga yang ditawarkan oleh Shopee Indonesia jauh lebih rendah dari e-commerce lainnya dengan atribut produk yang sama maka timbul persepsi bahwa ada sesuatu yang salah dari produk tersebut (contoh: pemalsuan produk) yang membuat persepsi nilai konsumen menjadi turun dan berdampak kepada menurunnya tingkat keputusan pembelian daring. Ditambah dengan kenyataan bahwa konsumen tidak bisa melihat wujud dari produk tersebut sebelum dibeli dan hanya bisa melihatnya dari gambar atau membaca informasi yang disediakan oleh penjual.

Hal ini diperkuat dengan penelitian yang dilakukan oleh Setiawan dan Achyar (2012) yang menyatakan bahwa harga terpersepsi berpengaruh negatif terhadap nilai yang didapat pelanggan dan keinginan untuk membeli daring.

\section{Pengaruh Harga terpersepsi sebagai Variabel Pemoderasi Terhadap Risiko terpersepsi dan Keputusan Pembelian}

Hasil penelitian menunjukkan bahwa harga terpersepsi dan keputusan pembelian daring tidak dipengaruhi oleh harga terpersepsi sebagai variabel pemoderasi (sig. $0.474<0.05$ ).

Persepsi adalah cara pandang tentang suatu hal dimana ada proses sebuah stimuli dipilih, diorganisir, dan diinterpretasikan menjadi informasi yang bermakna. Ketika konsumen sudah menstimuli cara pandangnya bahwa ecommerce ini memiliki tingkat risiko yang tinggi, walaupun penjual ecommerce tersebut memberikan harga yang terbaik maka tetap tidak akan memengaruhi keputusan konsumen untuk melakukan pembelian daring. Begitu juga sebaliknya, ketika konsumen sudah menstimuli cara pandangnya bahwa e-commerce ini memiliki tingkat risiko yang rendah, walaupun penjual e-commerce tersebut memberikan harga yang tinggi maka tetap tidak akan memengaruhi keputusan konsumen untuk melakukan pembelian daring.

Hal ini sejalan dengan penelitian Broillet, Dubosson, dan Varone (2014) yang menyatakan bahwa walaupun merek mahal menawarkan jaminan harga tetap tidak akan mengubah risiko terpersepsi konsumen untuk melakukan pembelian daring.

\section{Simpulan \\ SIMPULAN DAN SARAN}

Hasil penelitian yang dapat disimpulkan sebagai berikut : 
1. Keputusan pembelian daring dipengaruhi oleh kepercayaan secara positif. Artinya, semakin tinggi tingkat kepercayaan yang dirasakan oleh konsumen terhadap ecommerce Shopee Indonesia maka tingkat keputusan pembelian daring akan semakin meningkat.

2. Keputusan pembelian daring dipengaruhi oleh risiko terpersepsi secara negatif. Artinya, semakin rendah risiko terpersepsi yang dirasakan oleh konsumen terhadap e-commerce Shopee Indonesia, maka tingkat keputusan pembelian daring konsumen akan semakin tinggi.

3. Kepercayaan dan keputusan pembelian daring dipengaruhi oleh harga terpersepsi sebagai variabel pemoderasi. Tetapi pengaruh harga terpersepsi sebagai variabel pemoderasi memperlemah kepercayaan dan keputusan pembelian daring.

4. Risiko terpersepsi dan keputusan pembelian daring tidak dipengaruhi oleh harga terpersepsi sebagai variabel pemoderasi. Ketika konsumen sudah menstimuli cara pandangnya bahwa e-commerce ini berisiko tinggi maka tetap tidak akan memengaruhi keputusan konsumen untuk melakukan pembelian daring walaupun penjual e-commerce tersebut memberikan harga yang terbaik.

\section{Saran}

Saran yang bisa diberikan berdasarkan hasil penelitian ini adalah sebagai berikut:

1. Risiko terpersepsi responden terhadap keamanan dan informasi masih tinggi untuk e-commerce Shopee. Oleh sebab itu, Shopee
Indonesia sebaiknya mengambil langkah untuk menyeleksi kembali penjual yang bermitra dengan Shopee dan memberikan kebijakan tegas bagi penjual yang bermitra dengan Shopee Indonesia.

2. Untuk penelitian selanjutnya, sebaiknya meneliti tentang faktor nilai terpersepsi, manfaat terpersepsi, dan pengalaman sebelumnya sebagai variabel yang dapat memengaruhi keputusan pembelian daring.

3. Untuk penelitian selanjutnya, bisa meneliti platform $\mathrm{B} 2 \mathrm{C}$ e-commerce lainnya atau bisa meneliti social commerce.

\section{DAFTAR PUSTAKA}

Broillet, A., Dubosson, M., Varone, S. 2014. Risk Awareness from The Consumer's Side in Luxury ECommerce: An Empirical Study.

Demirdogen, O., et al. 2010. Customer Risk Perception of Internet Banking - A Study in Turkey. Journal of Applied Business Researc, Vol 26 (6), 57-68.

Hair, Joseph F. Jr., Christian M. Ringle, dan Marko Sarstedt. 2011. "PLSSEM: Indeed A Silver Bullet". Journal of Marketing Theory and Practice 19:139-13.

Hair, Joseph F. Jr., G. Tomas M. Hult, Christian M. Ringle, dan Marko Sarstedt. 2014. A Primer on Partial Least Squares Structural Equation Modeling (PLS-SEM). United States of America: SAGE Publications, Inc. Kindle Edition.

Harris, L. C. dan Goode, M. M. 2010. Online Servicescape, Trust, and 
Purchase Intention. Journal Of Service Marketing, Volume 24 (3), 230-243.

Kidane, T.T. dan Sharma, R.R.K. 2016. Factors Affecting Consumers' Purchasing Decision Through ECommerce. Proceedings of the 2016 International Conference on Industrial Engineering and Operations Management, 159165.

Kotler, Philip. 2011. Manajemen Pemasaran di Indonesia : Analisis, Perencanaan, Implementasi dan Pengendalian. Jakarta : Penerbit Salemba Empat.

Kotler, P. dan Armstrong, G. 2012. Prinsip-Prinsip Pemasaran Edisi 13. Jakarta: Erlangga.

Kotler, P. dan Keller, K.L. 2012. Marketing Management: $14^{\text {th }}$ Edition. New Jersey: Prentice Hall, Pearson Hall, Pearson Education, Inc.

Martiyanti, D. 2015. Perbedaan Gender Mengenai Perceived Risk Pada Pembelian Online. Kinerja Vol 12 (2), 140-149.

Mohmed., A.S.I., Azizan, N.B., Jali, M.Z. 2013. The Impact of Trust and Past Experience on Intention to Purchase in E-Commerce. International Journal of Engineering Research and Development, Vol 7 (10), 28-35.

Puspitasari, S.N. 2018. Konsumen Indonesia Habiskan 4 Menit saat Belanja Online [online] (diupdate 11 April 2018) Tersedia di: http://www.pikiranrakyat.com/hidup- gaya/2018/04/11/konsumenindonesia-habiskan-4-menit-saatbelanja-daring-422664.

Putera, A.D. 2018. The Big Start Indonesia: Mencermati Shifting Perilaku Konsumen di ECommerce [online] (diupdate 27 Juli 2018) Tersedia di: https://ekonomi.kompas.com/rea d/2018/07/27/131900326/thebig-start-indonesia--mencermatishifting-perilaku-konsumen-di-ecommerce.

Sharma, J.K dan Kurien, D. 2017. Perceived Risk in E-Commerce: A Demographic Perspective. NMIMS Management Review, Vol 34 (1), 31-57.

Setiawan, R. dan Achyar, A. 2012. Effects of Perceived Trust and Perceived Price on Customers' Intention to Buy in Online Store in Indonesia. Asean Marketing Journal, Vol 4 (1), 26-36.

Suryani, T. 2013. Perilaku Konsumen di Era Internet.Yogyakarta : Graha Ilmu. 
Business Management Journal Vol.14 (No. 2) : 75 - 153. Th. 2018 Hasil Penelitian 